Article

\title{
Corn Stover Removal Responses on Soil Test P and K Levels in Coastal Plain Ultisols
}

\author{
Jeffrey M. Novak ${ }^{1, * \mathbb{D}}$, James R. Frederick ${ }^{1}$, Don W. Watts ${ }^{1} \mathbb{D}$, Thomas F. Ducey ${ }^{1}$ and Douglas L. Karlen ${ }^{2} \mathbb{D}$ \\ 1 United States Department of Agriculture (USDA), Agricultural Research Service (ARS), Coastal Plains Soil, \\ Water and Plant Research Center, Florence, SC 29501, USA; jfrdrck@clemson.edu (J.R.F.); \\ don.watts@usda.gov (D.W.W.); tom.ducey@usda.gov (T.F.D.) \\ 2 D.L. Karlen Consulting LLC, St. Paul, MN 55102, USA; doug.karlen@gmail.com \\ * Correspondence: Jeff.novak@usda.gov; Tel.: +1-(843)-669-5203
}

Citation: Novak, J.M.; Frederick, J.R.; Watts, D.W.; Ducey, T.F.; Karlen, D.L. Corn Stover Removal Responses on Soil Test P and K Levels in Coastal Plain Ultisols. Sustainability 2021, 13, 4401. https://doi.org/10.3390/ su13084401

Academic Editor:

Bernhard Huchzermeyer

Received: 23 March 2021

Accepted: 14 April 2021

Published: 15 April 2021

Publisher's Note: MDPI stays neutral with regard to jurisdictional claims in published maps and institutional affiliations.

Copyright: (C) 2021 by the authors Licensee MDPI, Basel, Switzerland. This article is an open access article distributed under the terms and conditions of the Creative Commons Attribution (CC BY) license (https:// creativecommons.org/licenses/by/ $4.0 /)$.

\begin{abstract}
Corn (Zea mays L.) stover is used as a biofuel feedstock in the U.S. Selection of stover harvest rates for soils is problematic, however, because excessive stover removal may have consequences on plant available $\mathrm{P}$ and $\mathrm{K}$ concentrations. Our objective was to quantify stover harvest impacts on topsoil $\mathrm{P}$ and $\mathrm{K}$ contents in the southeastern U.S. Coastal Plain Ultisols. Five stover harvest rates $(0,25,50,75$ and $100 \%$ by wt) were removed for five years from replicated plots. Grain and stover mass with $\mathrm{P}$ and $\mathrm{K}$ concentration data were used to calculate nutrient removal. Mehlich 1 (M1)extractable $\mathrm{P}$ and $\mathrm{K}$ concentrations were used to monitor changes within the soils. Grain alone removed 13-15 kg ha ${ }^{-1} \mathrm{P}$ and $15-18 \mathrm{~kg} \mathrm{ha}^{-1} \mathrm{~K}$ each year, resulting in a cumulative removal of 70 and $85 \mathrm{~kg} \mathrm{ha}^{-1}$ or 77 and $37 \%$ of the $\mathrm{P}$ and $\mathrm{K}$ fertilizer application, respectively. Harvesting stover increased nutrient removal such that when combined with grain removed, a cumulative total of $95 \%$ of the applied P and $126 \%$ of fertilizer K were taken away. This caused M1 P and K levels to decline significantly in the first year and even with annual fertilization to remain relatively static thereafter. For these Ultisols, we conclude that $\mathrm{P}$ and $\mathrm{K}$ fertilizer recommendations should be fine-tuned for $\mathrm{P}$ and $\mathrm{K}$ removed with grain and stover harvesting and that stover harvest of $>50 \%$ by weight will significantly decrease soil test M1 P and K contents.
\end{abstract}

Keywords: cellulosic biomass; corn stover harvest; nutrient budget; plant available phosphorus (P) and potassium (K); Ultisols

\section{Introduction}

Harvesting corn stover (cobs, stems, leaves, and husks) following grain harvest for use as cellulosic feedstock to produce bioenergy or other bio-based products has received considerable attention for the past twenty years. Recognized as a countermeasure to help mitigate increasing atmospheric $\mathrm{CO}_{2}$ concentrations [1,2] and to off-set ever-growing global consumption of petroleum [3] for liquid fuels, sustainability of harvesting stover has been extensively studied. Ethanol and other organic alcohols (i.e., butanol, etc.) can be created by processing corn grain, sugarcane (Saccharum officinarum), algae and various other lignocellulosic feedstocks [4,5]. Alternatively, gas, liquid, and solid fuel phase forms of bioenergy can be produced from biomass using thermochemical conversion platforms such as co-firing, gasification, and both slow and fast pyrolysis [6,7].

With nearly 40 million hectares of corn production in the U.S., stover is one of the most abundant potential lignocellulosic feedstocks for biorefineries [8-10]. For 2020, dry biomass production was projected by the US-DOE [11] as being between 22 and $110 \mathrm{Mg}$ (24 and 122 million tons). However, even though it appears that there is a large amount of corn biomass available for biofuel production, there are several ecosystem services (protection against erosion, reducing evaporation, providing a carbon food source for microbes) and uses (animal feed and bedding) for this resource. Therefore, questions have arisen as to the 
sustainability of stover harvest [12], with one being its impact on soil fertility and long-term crop yield [13-15].

Determining sustainable corn stover removal levels is critical for maintaining soil fertility, physical properties, and subsequent crop yields [15]. However, establishing sustainable rates is challenging, as reflected by mixed relationships reported for harvest rate, crop yield, soil fertility and other site-specific characteristics. For example, Blanco-Canqui and Lal $[16,17]$ reported that $>25 \%$ crop residue removal caused declines in subsequent grain yields. Conversely, Birrell et al. [18] reported few effects on soil quality characteristics and crop yield after four years of various stover removal treatments, while other studies showed that $50 \%$ removal had little effect on succeeding crop productivity $[19,20]$.

Soil fertility declines due to increased plant nutrient removal associated with harvesting corn stover have been reported [10,13,21]. Karlen et al. [22] reported that compared to harvesting only the grain, removing an average of $3.9 \mathrm{Mg} \mathrm{ha}^{-1}$ of corn stover increased $\mathrm{P}$ and $\mathrm{K}$ removal by 2.7 and $31 \mathrm{~kg} \mathrm{ha}^{-1}$, respectively, while removing an average of $7.2 \mathrm{Mg} \mathrm{ha}^{-1}$, increased $\mathrm{P}$ and $\mathrm{K}$ removal to 5.5 and $62 \mathrm{~kg} \mathrm{ha}^{-1}$. Those removals are in addition to an average of 25 to $33 \mathrm{~kg} \mathrm{ha}^{-1}$ of $\mathrm{P}$ and $\mathrm{K}$, respectively, removed by the grain [23]. Failure to account for both grain and stover nutrient removal (especially for $\mathrm{P}$ and $\mathrm{K}$ ) can result in essential plant nutrient deficiencies as measured through soil testing. Both removal paths are also needed to compute plant nutrient budgets [24-26].

The impacts of crop residue removal on soil and plant nutrient measurements at the long-term research site [27] near where this study was conducted, were first quantified nearly 40 years ago [28]. Following publication of the Billion Ton Report [8] by the DOE and USDA, Karlen [28] coordinated a large-scale study to evaluate the dynamics of harvesting crop residue as feedstock for biofuels and/or bio-products. A consortium of soil scientists, agronomists, and engineers from several USDA-ARS locations, Land Grant Universities, and other federal agencies was assembled and directed to assess long-term sustainability of corn stover harvest, including its impact on soil quality (soil health) characteristics [29]. The multilocation, trans-disciplinary team quantified effects of various stover harvest rates on subsequent crop yield and several important soil quality indicators including soil test $\mathrm{P}$ and K. Several ARS and university locations conducted a coordinated 5 year field (2008 through 2012) experiment to assess effects of removing no, low, moderate, or high amounts of corn stover following grain harvest in seven different states (IA, IL, IN, $\mathrm{MN}, \mathrm{NE}, \mathrm{PA}$, and SC). The locations encompassed corn production practices typical of the Midwest, Northeast, and Southeastern regions of the U.S. An overall summary of yield and nutrient removal [22] and journal articles on various sustainability indicators [10] have been published, but detailed, site-specific assessments such as changes in soil test P and $\mathrm{K}$ concentrations or topsoil mass balances have not been reported for several of the locations including the site reported upon herein. The objectives, therefore, are to: (i) determine topsoil $(0$ to $15 \mathrm{~cm}) \mathrm{P}$ and $\mathrm{K}$ mass balance response to five stover harvest rates $(0,25,50,75$ and $100 \%$ of above-ground biomass from continuous corn plots, and (ii) evaluate changes in M1-extractable P and K concentrations in topsoil of toposequential Coastal Plain Ultisols.

\section{Methods and Materials}

\subsection{Site Description and Experimental Setup}

This field study was conducted at $34^{\circ} 17^{\prime} 18.5^{\prime \prime} \mathrm{N}, 79^{\circ} 44^{\prime} 16.3^{\prime \prime} \mathrm{W}$ on the Clemson University, Pee Dee Research and Education Center near Florence, SC. Twenty, $138 \mathrm{~m}^{2}$ plots were established using a randomized complete block design with each plot accommodating 12 of $15 \mathrm{~m}$ corn rows spaced $0.76 \mathrm{~m}$ apart. Plot size was selected to ensure the combine had sufficient time and travel distance to shell ears and eject stover.

Soil series mapped with each transect areas were classified as Ultisols and were representative of the Goldsboro-Lynchburg-Coxville/Rains toposequence. Geologically, the soils were formed between 0.5 and 5 million years BCE in loamy marine sediments or fluvio-marine sediments deposited within the Middle Coastal Plain physiographic 
region [30]. These soils are commonly found throughout the South Carolina Coastal Plain and have historically been used for agricultural crop production [31,32].

Daily rainfall was measured at the Pee Dee Weather Station Site no. $2037\left(34^{\circ} 18^{\prime} \mathrm{N}\right.$ and $79^{\circ} 44^{\prime} \mathrm{W}$ ) in Darlington County, SC for 2008 through 2012. The complete weather record is available through the USDA-NRCS National Water and Climate Center (https: $/ /$ wcc.sc.egov / nwcc/ site?sitenum $=2037 \&$ state $=S C$, accessed on 14 April 2021).

Tillage, agronomic and fertilizer management practices were typical for corn production in the South Carolina Coastal Plain region (Table 1). Prior to planting, fertilizer recommendations were determined by sampling soils in March of each year.

Table 1. Agronomic management practices.

\begin{tabular}{|c|c|c|c|c|c|}
\hline \multicolumn{5}{|c|}{ Fertilizer Applied (kg ha $\left.{ }^{-1}\right)$} & \multirow{2}{*}{$\begin{array}{c}\text { Planting Rate } \\
\text { Plants ha }\end{array}$} \\
\hline Year & $\mathbf{N}$ & $\mathbf{P}$ & $\mathbf{K}$ & Corn Cultivar & \\
\hline 2008 & 140 & 0 & 0 & DeKalb C69-71 & 49,505 \\
\hline 2009 & 140 & 20 & 50 & DeKalb C69-71 & 49,505 \\
\hline 2010 & 140 & 20 & 50 & DeKalb C69-71 & 54,455 \\
\hline 2011 & 99 & 17 & 42 & DeKalb C69-71 & 54,340 \\
\hline 2012 & 135 & 34 & 83 & DeKalb C69-71 & 54,450 \\
\hline
\end{tabular}

A final soil sampling was taken in March 2013 to compute a topsoil mass balance reflecting P and $\mathrm{K}$ additions and removals throughout the project. Eight, $2.5 \mathrm{~cm}$ diameter soil cores were randomly collected from each plot to a depth of $15 \mathrm{~cm}$. Samples were composited, air-dried, and analyzed for routine soil test parameters using M1 extraction at Clemson University's Soil Testing Laboratory (https: / www.clemson.edu/public/ regulatory/ag-srvc-lab/index.html, accessed on 14 April 2021). To convert concentration units of mass, soil bulk density samples were collected from the same depth increments using the core method described by [33].

Annual fertilizer application rates and plant populations are shown in Table 1. For N, liquid urea ammonium nitrate (UAN) was split applied at planting and the V6 corn growth stage, while except for 2008, granular P and $\mathrm{K}$ were applied annually in March. A 6-row, John Deere MaxEmerge XP no-till planter, attached to a Kelly Manufacturing Company (KMC) in-row subsoiler, was used to plant Dekalb C69-71 hybrid corn (a 114 day relativity maturity variety with an intermediate FAO mature date of 300-399). The seeding rate was 49,505 and 54,455 plants $\mathrm{ha}^{-1}$ in $0.76 \mathrm{~m}$ wide rows in mid-April of each year (Table 1). The in-row subsoiler, mounted in front of each planting coulter, is designed to disrupt a root-limiting hard pan (E horizon) at a depth of approximately $40 \mathrm{~cm}$ [34].

Corn stover (all above-ground plant parts, excluding grain) was collected from each plot using a "diaper method" that consisted of a canvas tarp mounted to the back of a commercial combine. This enabled us to collect $100 \%$ of the material passing through the machine. The wet corn stover captured by the canvas tarp was weighed in the field, and subsamples were taken for over drying and moisture content determined by weight. Knowing the total amount of corn stover collected for each plot, fractions representing 0, 25, 50,75 , and $100 \%$ on a wet weight basis were manually spread to establish specific removal rates for each plot. After determining stover moisture content, the wet stover weights were corrected to a dry weight basis for final reporting. The stover was spread by hand as uniformly as possible across each plot. Corn grain yield was determined by weighting the corn grain from each plot in a scale-equipped wagon. While transferring grain from the combine to the wagon, a sample was collected to determine moisture content and nutrient concentrations from which marketable yield and nutrient removal were calculated. 


\subsection{Corn Grain and Stover Analysis}

Grain and stover samples were analyzed for total $\mathrm{P}$ and $\mathrm{K}$ using ICP analysis after wet digestion [35] at the Clemson University Plant Testing Laboratory (https:/ /www.clemson. edu/public/regulatory/ag-srvc-lab/index.html, accessed on 14 April 2021). Concentrations for both nutrients were multiplied by harvest mass to quantify total $\mathrm{P}$ and $\mathrm{K}$ removal from each plot via grain or stover. Total $\mathrm{P}$ and $\mathrm{K}$ removal through grain harvest alone or grain plus any of the stover harvest treatments were computed by summing annual removal amounts (Table 2). Net mass balance changes were computed by subtracting total $\mathrm{P}$ and $\mathrm{K}$ removal annually and for the entire five years from amounts applied a fertilizer (Table 1). The differences between $\mathrm{P}$ and $\mathrm{K}$ removed/returned was determined and results expressed with a negative value indicate more $\mathrm{P}$ and $\mathrm{K}$ nutrients were removed in corn grain and stover than was replaced with inorganic fertilizer addition and as returned stover. Mehlich $1 \mathrm{P}$ and $\mathrm{K}$ concentrations were determined by depth and year for each treatment and expressed as $\mathrm{kg} \mathrm{ha}^{-1}$ after conversion using associate soil bulk density values.

Table 2. Annual mean corn stover (minus grain weight) removed and returned to plots (\% stover removed on a dry weight basis).

\begin{tabular}{|c|c|c|c|}
\hline \multirow{2}{*}{ Stover Removed (\%) } & \multicolumn{3}{|c|}{ Annual Mean Corn Stover ( $\mathrm{kg} \mathrm{ha}^{-1}$} \\
\hline & Year & Removed & Returned \\
\hline \multirow[t]{6}{*}{0} & 2008 & 0 & 6712 \\
\hline & 2009 & 0 & 8543 \\
\hline & 2010 & 0 & 6676 \\
\hline & 2011 & 0 & 4274 \\
\hline & 2012 & 0 & 7996 \\
\hline & mean & 0 & 6820 \\
\hline \multirow[t]{6}{*}{25} & 2008 & 1657 & 4970 \\
\hline & 2009 & 1919 & 5758 \\
\hline & 2010 & 1624 & 4871 \\
\hline & 2011 & 1138 & 3415 \\
\hline & 2012 & 1754 & 5263 \\
\hline & mean & 1618 & 4851 \\
\hline \multirow[t]{6}{*}{50} & 2008 & 3196 & 3197 \\
\hline & 2009 & 4056 & 4056 \\
\hline & 2010 & 3107 & 3107 \\
\hline & 2011 & 2393 & 2393 \\
\hline & 2012 & 3924 & 3924 \\
\hline & mean & 3335 & 3335 \\
\hline \multirow[t]{6}{*}{75} & 2008 & 4814 & 1618 \\
\hline & 2009 & 5839 & 1947 \\
\hline & 2010 & 5081 & 1693 \\
\hline & 2011 & 3528 & 1176 \\
\hline & 2012 & 5944 & 1981 \\
\hline & mean & 5041 & 1683 \\
\hline \multirow[t]{6}{*}{100} & 2008 & 6408 & 0 \\
\hline & 2009 & 8295 & 0 \\
\hline & 2010 & 6494 & 0 \\
\hline & 2011 & 4931 & 0 \\
\hline & 2012 & 7508 & 0 \\
\hline & mean & 6757 & 0 \\
\hline
\end{tabular}




\subsection{Statistical Analysis}

Nutrient removal by grain or grain plus a fraction of the stover and soil test $\mathrm{P}$ and $\mathrm{K}$ values were analyzed using an ANOVA with SigmaPlot v. 13.0 (SYSTAT Software, San Jose, CA, USA) software. For this ANOVA, experimental years were used as treatment replicates.

\section{Results and Discussion}

\subsection{Agronomic Practices}

Throughout the 5 year study, inorganic fertilizer was provided to all plots at rates from 99 to 140, 0 to 34 , and 0 to $83 \mathrm{~kg} \mathrm{ha}^{-1}$, for N, P, and K, respectively (Table 1). Baseline extractable $\mathrm{P}$ and $\mathrm{K}$ in 2008 indicated $\mathrm{P}$ and $\mathrm{K}$ were sufficient for Coastal Plain non-irrigated corn production, so only $\mathrm{N}$ was applied. Thereafter (2009-2011), modest amounts of $\mathrm{P}$ and $\mathrm{K}$ were applied, but decreasing soil test values resulted in application rates for these essential plant nutrients being nearly double in 2012 (Table 1). Meanwhile, planting rates which for the first two years were $<50,000$ plants ha $^{-1}$ were increased $\sim 10 \%$ to an average of 54,500 plants ha ${ }^{-1}$ to better align with higher corn populations in the SC Coastal Plain (J.R. Frederick, Personnel Communication, Clemson University, 2010).

\subsection{Stover Harvest Rates}

Annual stover removed and returned are presented in Table 2. For all five treatments, total above-ground mean corn stover removed from the plots ranged from 1618 to $6757 \mathrm{~kg} \mathrm{ha}^{-1}$. Overall aerial biomass production for the $0 \%$ removal treatment was similar to that reported by $[36,37]$. Those two studies reported corn stover production from 7683 to 8350 and 5934 to $9340 \mathrm{~kg} \mathrm{ha}^{-1}$, respectively, for studies with multiple years of corn grown on pedogenically similar Ultisols (i.e., Goldsboro, Norfolk, Rains series) with similar agronomic practices.

\subsection{Grain and Stover P and K Concentrations and Removal}

Corn grain from the various stover harvest treatments removed an average of 13 to $15 \mathrm{~kg} \mathrm{ha}^{-1}$ of $\mathrm{P}$ and 15 to $18 \mathrm{~kg} \mathrm{ha}^{-1}$ of $\mathrm{K}$ each year (Table 3). Cumulative $\mathrm{P}$ and $\mathrm{K}$ removal by grain alone, was 70 to $85 \mathrm{~kg} \mathrm{ha}^{-1}$, respectively, for the five stover removal treatments. A simple mass balance shows those removal quantities accounted for $77 \%$ of the collective $\mathrm{P}$ and $38 \%$ of the $\mathrm{K}$ applied as fertilizer (i.e., 91 and $225 \mathrm{~kg}$ of $\mathrm{P}$ and $\mathrm{K}$ : Table 1). Removing 25, 50, 75, or $100 \%$ of the above-ground biomass (i.e., stover), respectively, resulted in an average P removal of 2, 4, 5 and $6 \mathrm{~kg} \mathrm{ha}^{-1}$ (Table 3). Similar calculations for $\mathrm{K}$ show that stover harvest alone increased average annual removal by 20, 40, 60 and $79 \mathrm{~kg} \mathrm{ha}^{-1}$, respectively. Again, adding stover and grain removal together, the cumulative $\mathrm{K}$ removal increases to $37,55,78$, and $97 \mathrm{~kg} \mathrm{ha}^{-1}$, or $16,24,34$, and $43 \%$ of the total $\mathrm{K}$ fertilizer application ( $\sum 225 \mathrm{~kg} \mathrm{~K} ; 2008$ to 2012$)$. These $\mathrm{P}$ and $\mathrm{K}$ removals are similar to those reported by Karlen [28] for what they defined as moderate ( $50 \%)$ and high $(\sim 90 \%)$ harvest rates. These results suggest that harvesting grain and stover from Coastal Plain soils will require a reevaluation of fertilizer recommendations since their combined nutrient removal totals caused a lowering of M1-extractable P and K concentrations (see next section). This is a salient finding because $\mathrm{P}$ and $\mathrm{K}$ availability is a concern in the highly weathered Ultisols in the South Carolina Coastal Plain region [38]. These soils are inherently nutrient poor and have a poor ability to store nutrients because of low cation exchange capacities, low organic matter contents and sandy soil textures [39].

Results from Table 3 along with $\mathrm{K}$ and $\mathrm{P}$ fertilizer addition (Table 1) were used to calculate annual $\mathrm{K}$ and $\mathrm{P}$ mass balance estimates for each treatment system (Table 4). Overall, removal of 0,25 and $50 \%$ corn stover resulted, for the most part, in positive mass balance $\mathrm{K}$ and $\mathrm{P}$ values (Table 4). The positive values indicated that $\mathrm{K}$ and $\mathrm{P}$ were being resupplied to these three treatments. However, the amount of $\mathrm{K}$ and $\mathrm{P}$ returned were declining with increasing residue removal. The mass balance calculations revealed that removal of $75 \%$ corn stover caused corresponding M1 P and K topsoil reductions of -0.4 to $-12.5 \mathrm{~kg} \mathrm{ha}^{-1}$, respectively, while $100 \%$ removal increased M1 P and K losses to -2.6 to 
$-51.2 \mathrm{~kg} \mathrm{ha}^{-1}$ (Table 4). Statistical analyses revealed that the $\mathrm{P}$ and $\mathrm{K}$ removed at stover harvest amounts of $>50 \%$ were significantly different than corresponding nutrients removal at the lower amounts $(<50 \%)$.

Table 3. Mean phosphorus $(\mathrm{P})$ and potassium $(\mathrm{K})$ contents in corn grain and removed/returned under variable corn stover removal amounts (standard deviations in parentheses).

\begin{tabular}{|c|c|c|c|c|c|}
\hline \multirow[b]{2}{*}{ Nutrients in Corn Grain } & \multicolumn{5}{|c|}{$\%$ Corn Stover Removed $\left(\mathrm{kg} \mathrm{ha}^{-1}\right)^{\dagger}$} \\
\hline & 0 & 25 & 50 & 75 & 100 \\
\hline $\mathrm{P}$ & $14(7) \mathrm{a}$ & $14(6) \mathrm{a}$ & $13(6) \mathrm{a}$ & $15(7) \mathrm{a}$ & $14(6) \mathrm{a}$ \\
\hline K & $17(9) \mathrm{a}$ & $17(7) \mathrm{a}$ & $15(7) \mathrm{a}$ & $18(7)$ a & $18(7)$ a \\
\hline \multicolumn{6}{|l|}{ Stover P } \\
\hline removed & $0(0) \mathrm{a}$ & $2(0) b$ & $4(1) \mathrm{c}$ & $5(1) \mathrm{cd}$ & $6(2) d$ \\
\hline returned & $8(2) a$ & $6(1) b$ & $4(1) \mathrm{c}$ & $2(0.5) \mathrm{d}$ & $0(0) \mathrm{e}$ \\
\hline \multicolumn{6}{|l|}{ Stover K } \\
\hline removed & $0(0)$ a & $20(5) b$ & $40(10) \mathrm{c}$ & $60(15) d$ & 79 (17) e \\
\hline returned & $84(22) a$ & $61(14) b$ & $40(10) c$ & $20(5) d$ & $0(0) \mathrm{e}$ \\
\hline
\end{tabular}

${ }^{\dagger}$ Means between columns followed by a different letter are significantly different using an ANOVA at $p=0.05$ level of significance.

Table 4. Mean phosphorus (P) and potassium (K) mass balances from treatments under variable corn stover removal amounts (a negative value indicates more nutrient removed in corn grain and stover than replacement with inorganic fertilizer and returned corn stover; standard deviation in parentheses).

\begin{tabular}{cccccc}
\hline \multicolumn{5}{c}{ Nutrient Mass Balance $\left(\mathbf{k g ~ h a}^{-\mathbf{1}}\right)$} & \multicolumn{4}{c}{ Estimate for Each \% Stover Removal Amount ${ }^{+}$} \\
\hline Nutrient & $\mathbf{0}$ & $\mathbf{2 5}$ & $\mathbf{5 0}$ & $\mathbf{7 5}$ & $\mathbf{1 0 0}$ \\
\hline $\mathrm{P}$ & $12.6(11.9) \mathrm{a}$ & $8.4(11.5) \mathrm{a}$ & $5.5(11.6) \mathrm{a}$ & $-0.4(12.6) \mathrm{a}$ & $-2.5(11.7) \mathrm{a}$ \\
$\mathrm{K}$ & $116.5(51.6) \mathrm{a}$ & $68.9(35) \mathrm{ac}$ & $30.1(28.4) \mathrm{bc}$ & $-12.5(25) \mathrm{bd}$ & $-51.2(25.3) \mathrm{d}$ \\
\hline
\end{tabular}

${ }^{\dagger}$ Means between columns followed by a different letter are significantly different using an ANOVA at $p=0.05$.

\subsection{Soil Test $P$ and $K$}

One potential soil fertility repercussion of removing too much crop residue for biofuels, bio-products, or any other use is nutrient depletion [38,40]. Preventing depletion of essential plant nutrients in crop/biofuel production systems is the cornerstone for a well-managed soil fertility program. To maintain an appropriate nutrient balance, soil testing methods have been developed and nutrients exported from the field are typically replaced by adding animal manure and/or fertilizers $[40,41]$. Having quantified $\mathrm{P}$ and $\mathrm{K}$ removal in both grain and stover provided an excellent opportunity to evaluate not only effects of biomass removal, but also soil test sensitivity and fertilizer recommendations and nutrient use efficiencies.

The impact of various corn stover harvest rates on M1-extractable $\mathrm{P}$ and $\mathrm{K}$ in topsoil (0-15 cm depth) is presented for 2008 through 2013 in Figures 1 and 2. Grain harvest alone (i.e., no stover removal) as well as the four stover harvest treatments showed significant decreases in extractable $\mathrm{P}$ and $\mathrm{K}$, especially by 2010 . When fertilizer rates were increased (e.g., P applied in 2009 and 2011; K in 2011; Table 1), soil test values rose slightly, but not to original, pre-study levels (2008). 


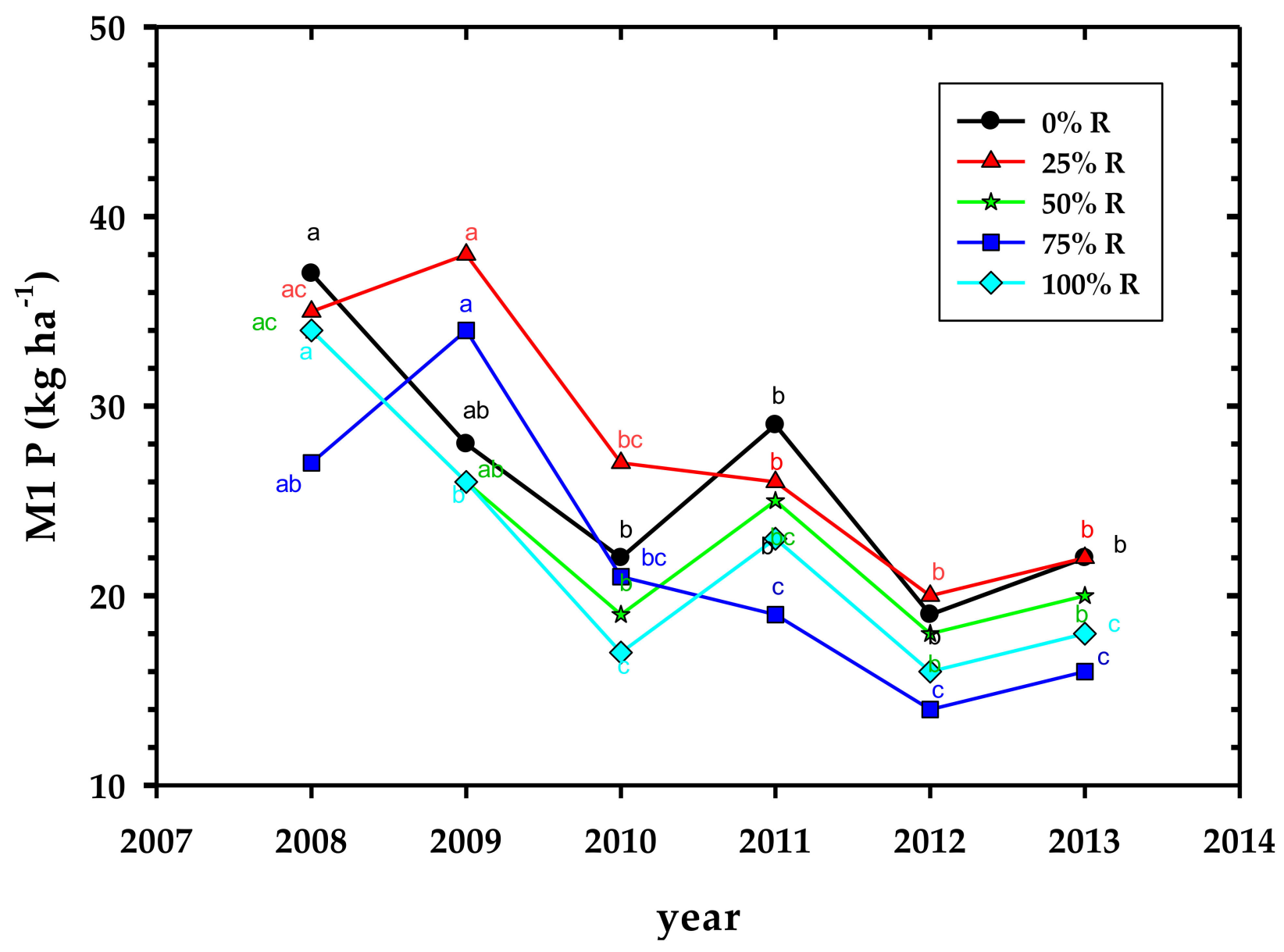

Figure 1. Annual mean topsoil Mehlich 1 (M1) phosphorus (P) concentrations versus percentage of dry corn stover removal $(\mathrm{R}$, means followed by a different letter are significantly different using an ANOVA at $p=0.05$ level of significance.

Mehlich 1-extractable concentrations of both nutrients showed significant decreases with P concentrations decreasing significantly by 2010 and K concentrations dropping significantly between 2008 and 2009 for stover harvest treatments (Figures 1 and 2). Soil test $\mathrm{P}$ and $\mathrm{K}$ concentrations continued to decline in subsequent years with the largest drop being in the 75 to $100 \%$ stover harvests. This is consistent with the $\mathrm{P}$ and $\mathrm{K}$ mass balance estimates (Table 4).

Failure to apply $\mathrm{K}$ fertilizer in 2008 resulted in a significant reduction in topsoil $\mathrm{K}$ concentration in just one year (Figure 2). Applying K fertilizer thereafter did not appreciably increase K concentrations, and in fact, they remained fairly static. By 2013, all treatments had soil test P and K concentrations much less than when the study started (2008). It is interesting that by 2013 , all treatments had very similar mean topsoil $\mathrm{K}$ concentrations (Figure 2; 42 to $53 \mathrm{~kg} \mathrm{ha}^{-1}$ ), irrespective of the amount of $\mathrm{K}$ removed in stover and grain or applied as fertilizer. In retrospect, the significant decline in M1 soil K between 2008 and 2009 emphasizes that attention must be given to managing $\mathrm{K}$ even though it does not have the potential negative environmental impacts that either $\mathrm{N}$ or $\mathrm{P}$ can have. Fertilizer replacement of $\mathrm{K}$ must equal or exceed the amount being removed rather than assuming traditional maintenance fertilization practices will be sufficient to maintain soil $\mathrm{K}$ levels throughout the profile. In spite of the noted declines, the corn plant were probably meeting their $\mathrm{K}$ demand by extracting available $\mathrm{K}$ from deeper profile depths, since this cation is known to leach from sandy-textured, low organic matter top soils [42,43] until it eventually accumulates in clay-enriched subsoil horizons [44]. 


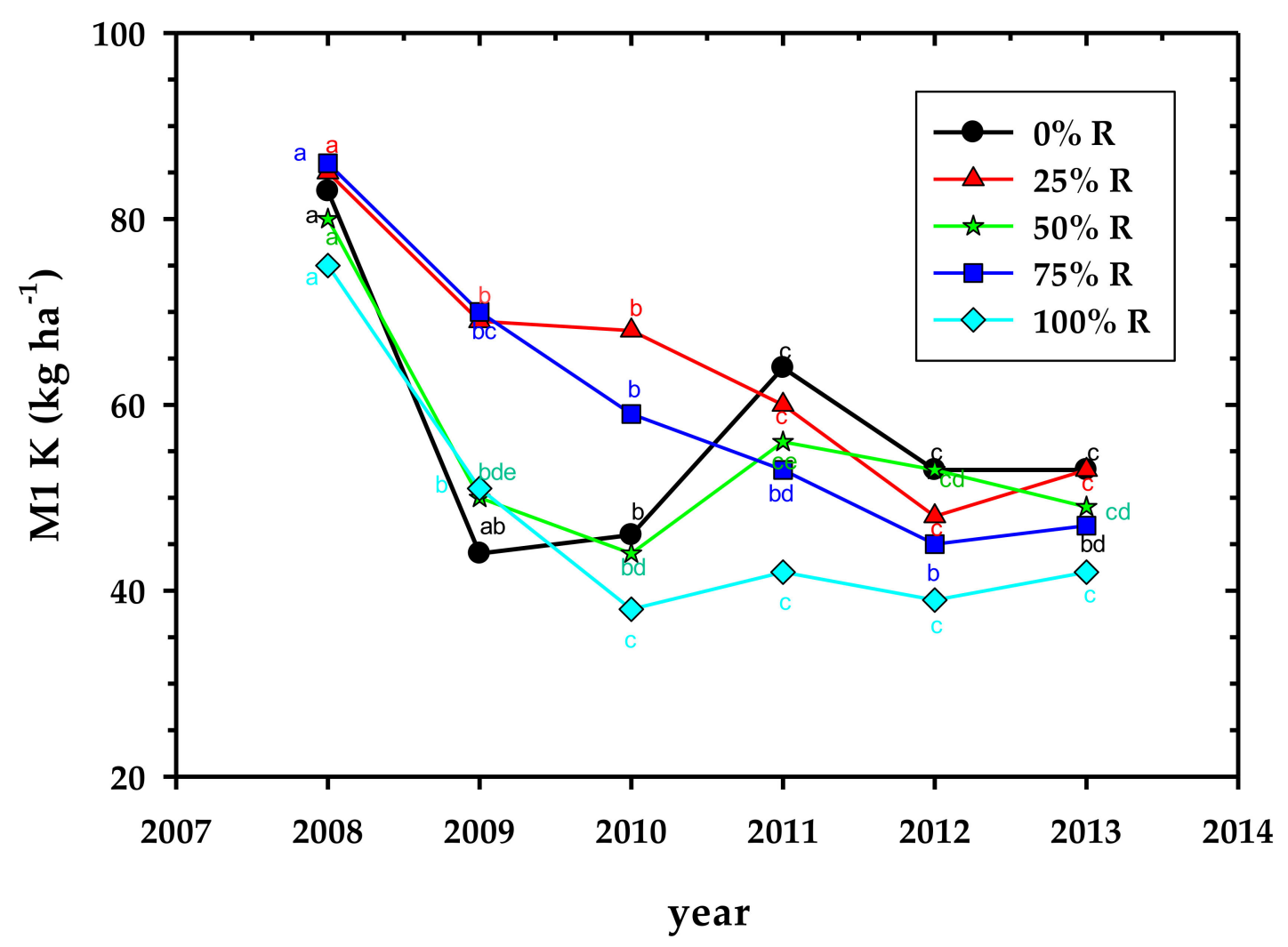

Figure 2. Annual mean topsoil Mehlich 1 (M1) potassium (K) concentrations versus percentage of dry corn stover removal $(\mathrm{R}$, means followed by a different letter are significantly different using an ANOVA at $p=0.05$ level of significance).

Some similar trends in M1-extractable P were also noted (Figure 1). Grain and stover harvest alone significantly decreased M1-extractable P when compared between 2008 and 2010, but thereafter mean P concentrations between years were similar (Figure 1). The need for additional annual $P$ fertilizer applications was verified by decreases of 11 to $16 \mathrm{~kg}$ ha $^{-1}$ M1-extractable P between 2008 and 2013 for all treatments (Figure 1). Fertilizer P was applied in 2009 through 2012 (Table 1), but the cumulative amount (91 kg ha ${ }^{-1}$ ) was not sufficient to return M1 P concentrations to baseline (i.e., 2008) levels. These results strongly suggest that $\mathrm{P}$ fertilizer recommendations for corn production on Coastal Plain soils need to be re-evaluated, since depletion occurred not only in stover harvest treatments, but also when only grain was harvested (i.e., $0 \%$ corn stover harvest treatments).

\section{Summary and Conclusions}

Research evaluating corn stover harvest for biofuel production has been a cyclic quest for over forty years, yet stakeholders still requested information on sustainable harvest levels to prevent soil quality degradation [45]. This information is especially germane for sustainable biofuel production using stover harvested from corn grown in nutrientimpoverish sandy Coastal Plain South Carolina Ultisols. Thus, this study focused on changes in M1-extractable $\mathrm{P}$ and $\mathrm{K}$ concentrations as affected by grain and stover harvest amounts. Removing between 0 and 100\% corn stover for five years from these sandy Ultisols increased P and K removal by 2 to 6 and 20 to $79 \mathrm{~kg} \mathrm{ha}^{-1}$, compared to grainonly harvest. Significant reductions of M1 P and K concentrations were most evident after removal of $>50 \%$ stover by weight. The substantial decrease in M1-extractable $\mathrm{P}$ and $\mathrm{K}$ concentrations suggests that fertilizer recommendations for corn stover harvesting in these Ultisols should be re-evaluated. This re-evaluation could include increasing $\mathrm{P}$ and $\mathrm{K}$ fertilizer applications to the Ultisols to maintain current ex-ante levels or as direct replacement at commensurate levels with that removed by grain and stover harvest. We forecast that this information will be useful for biofuel producers considering maintaining 
sustainable corn stover removal rates and for modelers determining economic costs for biofuel processing.

Author Contributions: Conceptualization, J.M.N. and J.R.F.; methodology, J.M.N., J.R.F. and D.W.W.; formal Analysis, J.M.N.; investigation, J.M.N., J.R.F., T.F.D. and D.W.W.; data curation, D.W.W.; writing—original draft preparation, J.M.N.; writing—review and editing, J.M.N., D.L.K. and J.R.F. All authors have read and agreed to the published version of the manuscript.

Funding: This research received no external funding.

Institutional Review Board Statement: Not applicable.

Informed Consent Statement: Not applicable.

Data Availability Statement: No new data were created or analyzed in this study. Data sharing is not applicable to this article.

Acknowledgments: The authors express gratitude for the involvement of the research staff and field operators of the USDA-ARS-Coastal Plains Soil, Water and Plant Research Center and Clemson University, Pee Dee Research and Education Center for completing this project. This research was funded by the USDA-ARS Resilient Economic Agriculture Practices (REAP) project with additional funds from the Department of Energy (DOE) Bioenergy Technologies Office's regional Feedback Partnership Corn Stover Team, administered by the North Central Regional Sun Grant center at South Dakota State University under DOE award number DE-FC36-05GO85041. Mention of any trade names or commercial products does not constituent and endorsement or recommendation by the USDA for their use. The USDA is an equal opportunity employer.

Conflicts of Interest: The authors declare no conflict of interest.

\section{References}

1. Berndes, G.; Hoogwijk, M.; van den Brock, R. The contribution of biomass in the future of global energy supply: A review of 17 studies. Biomass Bioenergy 2003, 25, 1-28. [CrossRef]

2. Intergovernmental Panel on Climate Change [IPCC]. Climate Change 2007: The Physical Science Basis. Summary for POLICYMAKERS. Intergovernmental Panel on Climate Change, Geneva, Switzerland. Available online: http://www.ipcc.ch (accessed on 12 March 2021).

3. National Academy of Sciences (NAS). Liquid Transportation Fuels from Coal and Biomass: Technological Status, Costs, and Environmental Impacts; The National Academies Press: Washington, DC, USA, 2009.

4. Naik, S.N.; Vaibhav, V.G.; Rout, P.K.; Dalai, A.K. Production of first and second generation biofuels: A comprehensive review. Renew. Sustain. Energy 2010, 14, 578-597. [CrossRef]

5. Lee, J.W. Introduction: An overview of advanced biofuels and bioproducts. In Advanced Biofuels and Bioproducts; Springer: New York, NY, USA, 2013. [CrossRef]

6. Demirbas, A.; Gönenç, A. An overview of biomass pyrolysis. Energy Sources 2002, 24, 471-482. [CrossRef]

7. Lv, D.; Xu, M.; Liu, X.; Zhan, Z.; Li, Z.; Yao, H. Effects of cellulose, lignin, alkali and alkaline earth metallic species on biomass pyrolysis and gasification. Fuel Process. Technol. 2010, 91, 903-909. [CrossRef]

8. Perlack, R.D.; Wright, L.L.; Turnhollow, A.F.; Graham, R.L.; Stokes, B.J.; Erbach, D.C. Biomass as a Feedstock for a Bioenergy and Bioproducts Industry: The Technical Feasibility of a Billion-Ton Annual Supply. 2005; DOE/GO-102005-2135 and ORNL/TM2005/66. Available online: http:/ / feedstockreview.ornl.gov/pdf/billion_ton_vision.pdf (accessed on 12 March 2021).

9. Biomass Research and Development Board. Increasing Feedstock Production for Biofuels. In Economic Drivers, Environmental Implications, and the Role of Research; USDA: Washington, DC, USA, 2008. Available online: http://www.brdisolutions.com/site\% 20DOCs/increasing\%20Feedstock_revised.pdf (accessed on 12 March 2021).

10. Karlen, D.L.; Johnson, J.M.F. Crop residue considerations for sustainable bioenergy feedstock supplies. Bioenergy Res. 2014, 7 , 465-467. [CrossRef]

11. Langholtz, M.H.; Stokes, B.J.; Eaton, L.M. 2016 Billion-Ton Report: Advancing Domestic Resources for a Thriving Bioeconomy; Office of Scientific and Technical Information (OSTI); US Department of Energy, Forrestal Building: Washington, DC, USA, 2016 ; p. 448. [CrossRef]

12. Wilhelm, W.W.; Hess, J.R.; Karlen, D.L.; Johnson, J.M.F.; Muth, D.J.; Baker, J.M.; Gollany, H.T.; Novak, J.M.; Stott, D.E.; Varvel, G.E. Review: Balancing limiting factors and economic drivers for sustainable Midwestern US agricultural residue feedstock supplies. Ind. Biotechnol. 2010, 6, 271-287. [CrossRef]

13. Karlen, D.L.; Birrell, S.J.; Hess, J.R. A five-year assessment of corn stover harvest in central Iowa, USA. Soil Tillage Res. 2011, 115-116, 47-55. [CrossRef]

14. Zhao, G.; Bryan, B.A.; King, D.; Luo, Z.; Wang, E.; Yu, Q. Sustainable limits to crop residue harvest for bioenergy: Maintaining soil carbon in Australia's agricultural lands. GCB Bioenergy 2015, 7, 479-487. [CrossRef] 
15. Cherubin, M.R.; Oliveria, D.M.; Feigl, B.J.; Pimental, L.G.; Lisboa, I.P.; Gmach, M.R.; Varanda, L.L.; Morais, M.C.; Satiro, L.S.; Popin, G.V.; et al. Crop residue harvest for bioenergy production and its implication on soil functioning and plant growth: A review. Sci. Agric. 2018, 75, 255-272. [CrossRef]

16. Blanco-Canqui, H.; Lal, R. Soil and crop response to harvesting corn residues for biofuel production. Geoderma 2007, 141, 355-362. [CrossRef]

17. Blanco-Canqui, H.; Lal, R. Crop residue removal impacts on soil productivity and environmental quality. Crit. Rev. Plant Sci. 2009, 28, 139-163. [CrossRef]

18. Birrell, S.J.; Karlen, D.L.; Wirt, A. Development of sustainable corn stover harvest strategies for cellulosic ethanol production. Bioenergy Res. 2014, 7, 516-590. [CrossRef]

19. Kenny, I.; Blanco-Canqui, H.; Presley, D.R.; Rice, C.W.; Janssen, K.; Olson, B. Soil and crop responses to stover removal from rainfed and irrigated corn. GCB Bioenergy 2015, 7, 219-230. [CrossRef]

20. Jin, V.L.; Schmer, M.R.; Wienhold, B.J.; Stewart, C.E.; Varvel, G.E.; Sindelar, A.J.; Follett, R.F.; Mitchell, R.B.; Vogel, K.P. Twelve years of stover removal increases soil erosion potential without impacting yield. Soil Sci. Soc. Am. J. 2015, 79, 1169-1178. [CrossRef]

21. Adler, P.R.; Rau, B.M.; Roth, G.W. Sustainability of corn stover harvest strategies in Pennsylvania. Bioenergy Res. 2015, 8, 1310-1320. [CrossRef]

22. Karlen, D.L.; Birrell, S.J.; Johnson, J.M.F.; Osborne, S.L.; Schumacher, T.E.; Varvel, G.E.; Ferguson, R.B.; Novak, J.M.; Frederick, J.R.; Baker, J.M.; et al. Multilocation corn stover harvest effects on crop yields and nutrient removal. Bioenergy Res. 2014, 7, 528-539. [CrossRef]

23. Tan, Z.; Liu, S. Soil nutrient budgets following projected corn stover harvest for biofuel production in the conterminous United States. GCB Bioenergy 2014, 71, 1-19. [CrossRef]

24. Karlen, D.L.; Flannery, R.L.; Sadler, E.J. Aerial accumulation and portioning of nutrients by corn. Agron. J. 1988, 80, 232-242. [CrossRef]

25. Johnson, J.M.F.; Papiernik, S.K.; Mikha, M.M.; Spokas, K.; Tomer, M.D.; Weyers, S.L. Soil Processes and Residue Harvest Management. In Soil Quality and Biofuel Production; Lal, R., Stewart, B.A., Eds.; CRC Press: Boca Raton, FL, USA, 2010; pp. 1-44.

26. Setiyono, T.D.; Walters, D.T.; Cassman, K.G.; Witt, C.; Dobermann, A. Estimating maize nutrient uptake requirements. Field Crop. Res. 2010, 118, 158-168. [CrossRef]

27. Novak, J.M.; Watts, D.W.; Bauer, P.J.; Karlen, D.L.; Hunt, P.G.; Mishra, U. Loamy sand soil approaches organic carbon saturation after 37 years of conservation tillage. Agron. J. 2020, 112, 3152-3162. [CrossRef]

28. Karlen, D.L. Corn stover feedstock trials to predictive modeling. GCB Bioenergy 2010, 2, 235-247. [CrossRef]

29. Owens, V.N.; Karlen, D.L.; Lacey, J.A. Regional Feedstock Partnership Summary Report: Enabling the Billion-Ton Vision. In Regional Feedstock Partnership Summary Report: Enabling the Billion-Ton Vision; US Department of Energy: Washington, DC, USA, 2016. [CrossRef]

30. Daniels, R.B.; Buol, S.W.; Kleiss, H.J.; Ditzler, C.A. Soil Systems in North Carolina; Technical Bulletin 314; North Carolina State University: Raleigh, NC, USA, 1999.

31. Gray, L.C. History of Agriculture in the Southern United States to 1860; Carnegie Institute: Washington, DC, USA, 1933.

32. Trimble, S.W. Man-Induced Soil Erosion of the Southern Piedmont: 1700-1970; Soil Conservation Society of America: Ankeny, IA, USA, 1974.

33. Grossmann, R.B.; Reinsch, T.G. Bulk density and linear extensibility. In Methods of Soil Analysis. Part 4; Dane, J.H., Topp, G.C., Eds.; SSSA: Madison, WI, USA, 2002; pp. 201-228.

34. Busscher, W.J.; Bauer, P.J.; Frederick, J.R. Recompaction of a coastal loamy sand after deep tillage as a function of subsequent cumulative rainfall. Soil Tillage Res. 2002, 68, 49-57. [CrossRef]

35. Mills, H.A.; Jones, J. Plant Analysis Handbook II: Practical Sampling, Preparation, Analysis, and Interpretation Guide; Micro-Macro Publisher: Athens, GA, USA, 1996.

36. Novak, J.M.; Frederick, J.R.; Bauer, P.J.; Watts, D.W. Rebuilding organic carbon contents in coastal plain soils using conservation tillage systems. Soil Sci. Soc. Am. J. 2009, 73, 622-629. [CrossRef]

37. Novak, J.M.; Sigua, G.C.; Ducey, T.F.; Watts, D.W.; Stone, K.C. Designer biochar impact on corn grain yields, biomass production, and fertility properties of a highly-weathered Ultisol. Environments 2019, 6, 64. [CrossRef]

38. Karlen, D.L.; Hunt, P.G.; Campbell, R.B. Crop residue removal effects on corn yield and fertility of a Norfolk sandy loam. Soil Sci. Soc. Am. J. 1984, 48, 868-872. [CrossRef]

39. Odum, E.P.; Pinder, J.E., III; Christiansen, T.A. Nutrient losses from sandy soils during old-field succession. Am. Midl. Nat. 1984, 111, 148-154. [CrossRef]

40. Karlen, D.L.; Kovar, J.; Birrell, S. Corn stover nutrient removal estimates for central Iowa. Sustainability 2015, 7, 8621-8634. [CrossRef]

41. Lindstrom, M.J. Effects of residue harvesting on water runoff, soil erosion, and nutrient loss. Agric. Ecosyst. Environ. 1986, 16, 103-112. [CrossRef]

42. Kolahchi, Z.; Jalali, M. Effect of water quality on the leaching of potassium from sandy soil. J. Arid. Environ. 2007, 68, 624-639. [CrossRef] 
43. Wulff, F.; Schulz, V.; Jungk, A.; Claassen, N. Potassium fertilization on sandy soils in relation to soil test, crop yields and K-leaching. Z. Pflanz. Bodenkd. 2011, 161, 591-599. [CrossRef]

44. Rao, C.S.; Rupa, T.R.; Rao, A.S.; Bansal, S.K. Subsoil potassium availability in twenty-two benchmark soil series of India. Commun. Soil Sci. Plant Anal. 2007, 32, 863-876. [CrossRef]

45. Johnson, J.M.F. A “Soil Lorax" perspective on corn stover for advanced biofuels. Agron. J. 2018, 110, 59-62. [CrossRef] 